1. 研究課題名 : 多樣な電子相と相転移を有する低次元無機·有機ハイブリッド化合物

2 . 研究者名：山下 正廣

3 . 研究のねらい:

有機・無機ハイブリッド化合物は、無機の特徵 (電子の多樣性、スピン状態の多樣性、立体化学 の多樣性等) と有機の特徵 (構造の多樣性、設計の容易な分子等) をうまく組み合わせることによ り、従来の無機物あるいは有機物を超える物性か期待される。本研究対象とする化合物は (1) 擬 一次元鎖ハロゲン架橋白金系混合原子価錯体と、(2) S=1,2 ハルデンギャップ系化合物である。

(1) は電子格子相互作用、電子相関、電子移動の競合するパイエルス・ハドード系物質であり、 CDW、SDW 金属相などを取り得る。また、ソリトンやポーラロンの生成も制御できる。この化合物 において、化学成分の組み合わせ、ドーピング、光誘起、磁㪚誘起により、パイエルス・ハベード系 の本質を解明する。また、（２）の相転移に関する研究は皆無であり、圧力誘起、磁場誘起相転移の 研究によりハルデンギャップ系の電子状態の本質の解明を行う。

\title{
4. 研究結果及び自己評価:
}

擬一次元鎖ハロゲン架橋金属錯体は大きな電荷移動吸収帯、高次の共鳴ラマン散乱、大きなス トークスシフトをもつ発光、ソリトンやポーラロンに基づくミッドギャップの吸収、大きな三次非線形 光学効果などを示すことから興味か持たれている物質群である。金属イオンが Pd の場合は電子 格子相互作用か強いために架橋ハロゲンが金属間の中央からずれた $M(I I)-M(I V)$ 混合原子価状 態(CDW)をとるが、 Ni の場合は架橋ハロゲンは電子相関か強いために架橋ハロゲンは金属間の 中央にあるモット・バ゙ード状態(SDW)をとる。このように Pd と Ni は基底状態か全く異なっている。 もし、単結晶中で Ni と Pd の混晶した Ni1- xPdx(chxn)2Br3 が得られるならば電子格子相互作用と 電子相関力競合することによりどんな電子状態をとるのであろうか?光の点を解明するために、光 れらの混晶 Ni1- xPdx(chxn)2Br3を電気化学的酸化法により単結晶として得ることを試み、作製に 成功した。X 線結晶解析の結果、 $\mathrm{Ni}$ と Pd は連続的に混ざっていることがわかった。単結晶反射ス ペクトル、赤外スペクトル、ラマンスペクトル、XPS、E SR浿定などの結果から Ni の比率か増える につれてPd の CDW 状態が次第にSDW 状態へと変化することを見出した。つまり単独では安定 に存在しない Pd の SDW 状態力初めて達成されたのである。これは、Ni の電子相関が非常に強 い(〜6 eV)でためある。

今後はホールドーピングを試みるために Ni(III)- Co(III)混晶系を試みる予定である。このことによ り電荷移動吸収帯がより低エネルギーに移ることにより、大きな三次非線形光学効果か期待され る。

\section{5 . 領域総括の見解：}

架橋型白金系混合原子価錯体の研究は、光物性と合成化学の境界領域での独自の研究成果 
によって、世界的に日本のお家芸的分野として認知されている。炎の中で、本研究者は、典型的な 低次元白金系錯体の合成に関して、従来より指導的な役割を演じてきた中堅研究者である。本領 域での3 年間の研究は、光の発展的継続であり、光の中からいくつかの世界的水準の成果か得ら れたことは、評価できる。ただし、合成化学の研究では、個人レベルの発想や研究実施か涃難であ り、多分に集団指導体制スタイルに馴染みやすい。本研究者の多年の実績と、この3年間の本領 域での異分野交流の経験を活かして、今後、常識的発想を逸脱した飛躍的展開がもたらされるこ とを期待したい。

\section{6 . 主な論文}

1)Gigantic Optical Nonlinearlity in One- Dimensional Mott- Hubbard Insulators

H. Kishida, H. Matsuzaki, H. Okamoto, T. Manabe, M. Yamashita, Y. Taguchi, and

Y. Tokura

Nature, 405, 929 (2000)

2)First Syntheses of Cocrystallites Consisting of Anti- Formed Metal

Octaethylporphyrins with Fulleren $\mathrm{C} 60$

T. Ishi, N. Aizawa, H. Hara, M. Yamashita, H. Matsuzaka, K. Kikuchi, T. Kodama,

I. Ikemoto, and Y. Iwasa

J. Chem. Soc., Dalton, 2000, 4407 